\title{
Survivor of Sexual Violence in Quranic Perspective: Mubādalah Analysis toward Chapter Joseph in Tafsir al-Azhar
}

\author{
Muhammad Haris Fauzi, ${ }^{1}$ \\ Yuyun Affandi, ${ }^{2}$ Arikhah $^{3}$ \\ 1,2,3 Universitas Islam Negeri Walisongo \\ Semarang-Indonesia \\ Corresponding Author: Yuyun Affandi, \\ email:yuyunaffandi@walisongo.ac.id, \\ J. Prof. HAMKA, Kampus 3, Tambakaji, \\ Semarang, Indonesia 50185
}

\begin{abstract}
This research aims to examine and understand cases of sexual violence that befell the Prophet Joseph that was recorded in the verses of the Quran. The Prophet Joseph as a survivor of sexual violence suffered from verbal sexual harassment, attempted rape compulsion, and victim-blaming. The data is obtained by library research and analyzed using the sociohistorical approach and qirä'ah mubādalah to analyze the method. The research results indicate that men and women must create a safe space of sexual violence and avoid destructive actions. The Prophet Joseph's strategic move came out of the circle of sexual violence and became a survivor by implementing the unity of God's values in various conditions.
\end{abstract}

Keywords: survivor; sexual violence; sexual harassment; equality

\begin{abstract}
Abstrak: Penelitian ini bertujuan untuk mengkaji dan memahami kasus kekerasan seksual yang menimpa Nabi Yusuf yang terekam dalam ayat-ayat al-Qur'an. Nabi Yusuf sebagai penyintas kekerasan seksual mengalami pelecehan seksual verbal, percobaan paksaan pemerkosaan, dan menyalahkan korban. Data diperoleh dengan studi pustaka dan dianalisis menggunakan pendekatan sosio-historis dan metode analisis qirā'ah mubādalah. Hasil penelitian menunjukkan bahwa laki-laki dan perempuan harus menciptakan ruang aman dari kekerasan seksual dan menghindari tindakan destruktif. Langkah strategis Nabi Yusuf keluar dari lingkaran kekerasan seksual dan menjadi survivor dengan mengimplementasikan nilai-nilai keesaan dan ketuhanan dalam berbagai kondisi.
\end{abstract}

Kata Kunci: korban; kekerasan seksual; pelecehan seksual; kesetaraan

\section{A. Introduction}

Sexual violence is a complicated and sensitive subject involving the use of terms such as rape or sexual abuse or domestic violence and sexual harassment, to name a few. All of these terms immediately provoke weird feelings. 
Reporting on sexual violence means discussing issues that are often considered 'taboo,' and talking publicly about intimate and distressing matters. ${ }^{1}$

Harassment and sexual violence often occur around us. The public was subjected to multiple cases of abuse and sexual abuse of women. The case is not enough to raise the parties to anticipate and resolve the case. One such example is in the case of Baiq Nuril. ${ }^{2}$ The case is a real example of the act of rape and blame for the victims of sexual harassment occurring in Indonesia. Acts of sexual harassment arise from an environment that considers ordinary and forgiving perpetrators of sexual violence and makes it a part of local culture. ${ }^{3}$

National Commission on Violence against Women through an annual record of 2018 noted that cases of sexual violence experienced 14\% increase. The number of cases of violence against women in 2018 as much as 406,178, the number increased from the previous year in the number 348,466. ${ }^{4}$ The behavior of violence and sexual harassment can originate from the use of misogynistic language and the objectification of the female body to give chance to a society that is ignore to women's rights and safety. Sexual violence relates to any action that has an element of mayhem that has a sexual case. ${ }^{5}$

Sexual violence is often repeated in the range of human history, and the female may be the object of the violence. We take an example of the case of a husband's beating wife and various cases of other sexual violence involving and linking it to the evidence of religious texts that are in the Quran and Hadith. The Prophet with his wife and the given hadith that legitimized violence against wives became a theological alibi. Therefore, the Quran and hadith seemed to be sexually violent against women. ${ }^{6}$

\footnotetext{
${ }^{1}$ Raistick Nick, Reporting on Gender Based Violence in the Syiria Crisis: A Journalist's Handbook (England: UNFPA, 2014), 4.

2Felix Nathaniel, "Baiq Nuril, Korban Pelecehan Seksual Yang Dipidana Gara-Gara UU ITE," Tirto.ID, 2018, https://tirto.id/baiq-nuril-korban-pelecehan-seksual-yang-dipidana-gara-gara-uuite-c9QH.

${ }^{3}$ Citra Maudy, "Nalar Pincang UGM Atas Kasus Perkosaan," Balairung Press, 2018, https://www.balairungpress.com/2018/11/nalar-pincang-ugm-atas-kasus-perkosaan/.

${ }^{4}$ Komisi Nasional Anti Kekerasan terhadap Perempuan, "Lembar Fakta dan Catatan Tahunan Komnas Perempuan Tahun 2018” (Jakarta: Komnas Perempuan, 2018).

${ }^{5}$ Farha Ciciek, Ikthiar Mengatasi Kekerasan dalam Rumah Tangga (Jakarta: The Asian Foundation, 1999), 15.

${ }^{6}$ Masthuriyah Sa'dan, "Reinterpretasi Teologi Kekerasan Seksual terhadap Perempuan: Kajian Tafsir Amina Wadud," Jurnal Perempuan 21, no. 2 (2016): 163-70.
} 
Islam certainly encourages the elimination of sexual violence. It is recorded by the word of the Quran positioning itself as an instrument that is nurturing against victims especially women and children. The Quran puts men and women equally in the spirit of Allah.7

Through its teachings, Islam conveyed the mediator of the prophetic treatise liberate women from a system that tends to Arab patriarchy in Jahiliyyah, such as not limiting people to marry and killing a baby girl into a right that is worth fighting. ${ }^{8}$

The story of Joseph and Zulaikha opened the curtain about the importance of advocacy against victims and it is a concrete form of the case of sexual violence survivors that are contained in the word of Quran in some verses of Joseph's chapter. Joseph's personal as a victim has a not equal position and tends to be dominative. It is certainly suggestive and possible for sexual violence. Joseph's personal patiently faced the slander and temptation of his employer, the King's consort with all its fascination and beauty. The Empress who had honorable social status tempted Joseph and shut his room's doors. At that time, Joseph was in the pinnacle of his glory and away from his relatives.

In such a condition, rational male sexual desire is very dominant, but Joseph still has a strong faith and perfection to do sincere that makes him able to banish his desires. It should be noted that victims of sexual violence are not gender restricted; male and females can be the victim. ${ }^{9}$

God speaks in QS. Joseph [12]: 30, Hamka describes about the possibility of the age of the slander in a psychiatric, explaining the chronological occurrence of the event holistically and the problem of the problems experienced by the prophet Joseph. ${ }^{10}$

Various factors have stated that why the young king's wife had a heart with Joseph. Hamka quoted that the young king was impotent or so weak that

\footnotetext{
${ }^{7}$ Nurjannah Ismail, Perempuan dalam Pasungan Bias Laki-Laki dalam Penafsiran (Yogyakarta: LKiS, 2003), 10.

${ }^{8}$ Amirudin Arani and Faqihuddin Abdul Kodir, Tubuh, Seksualitas dan Kedaulatan Perempuan (Yogyakarta: Rahima, 2002), 107.

${ }^{9}$ Mariam Nabilah Mohd Noor and Mohd Shafiee Hamzah, "Defamation by Women Mentioned in Surah Yusuf According to Hamka: A Review," International Journal of Academic Research in Business and Social Sciences 7, no. 12 (2018): 631-39, https://doi.org/10.6007/IJARBSS/v7i12/3645.

${ }^{10}$ Hamka, Tafsir al-Azhar, vol. 5 (Singapura: Pustaka Nasional PTE Ltd., 1990), 3625.
} 
the wife of the young king did not feel the satisfaction of sexual intercourse with her husband. Gradually, the wife of king the younger became more immature to Joseph's personal. During the time, the wife of the king of the younger was increasingly put in love with the valiant and mighty person of Joseph. Until one when the wife of the king of young could no longer stem the turmoil of love and orgasm to Joseph.

God said in QS. Joseph [12]: 23, Hamka interprets that the king's wife struggling and painstakingly controls himself when he sees Joseph's still innocent personal. When a woman is already wooing and the situation of the house is no one. Of course, we can understand how to seduce the young king's wife, perhaps by being able to get a part of her sensual body that causes her to be a man. ${ }^{11}$ The verse suggests that the Prophet Joseph as a survivor of sexual violence. The Prophet Joseph attempted to avoid the deception of physical sexual harassment committed by Zulaikha.

Hamka explained that in verses QS. Joseph [12]: 26-27 above indicates an event or case needs to be accompanied by concrete evidence and indicators to see the origin of an issue including sexual harassment. Pay attention to chronological events for clear viewing of events occurring. Joseph gave a logical argument to the accusations raised by the king's consort. ${ }^{12}$

The position of women as described in some interpretations, through the interpretation of verses of the Quran precisely asserts that the seduction and temptation of women is more dangerous than satan. Even brands don't flirt, just shut up. It's been able to dissociate and distract men's minds. Some interpretations are incorrect with the idea of the Quran that puts men and women in the same position, whereas the thing that distinguishes them is only the level of self-righteousness.

In previous research, the issue of sexual violence and women has become an interesting study that some researchers have discussed; Mohd Noor expressed Hamka's view of the slanderous behavior and sexual harassment committed by women in Joseph's chapter. He said that throughout life man has the potential of anger, appetite and sexual desire towards women, but he did not detail how humans take preventive measures against it. ${ }^{13}$ Azman bin Mohd

\footnotetext{
${ }^{11}$ Hamka, Tafsir al-Azhar.

${ }^{12}$ Hamka, 5:3632. A Review."

${ }^{13}$ Noor and Hamzah, "Defamation by Women Mentioned in Surah Yusuf According to Hamka:
} 
Noor and Ahmad Basri bin Ibrahim also revealed that rape victims are in double danger because they experience unwanted aggression and inner conflict against them, which makes them suffer physically and mentally. ${ }^{14}$

From previous research, it has been found that the issue of sexual violence is associated with the influence of seduction, charm, and attractiveness of women. This paper is important because it is intended to fill the study of sexual violence against Joseph using a socio-historical approach that focuses on the viewpoint of reciprocal or mubädalah. The interesting thing is that this paper presents an analysis and discussion of the issue of sexual violence against Joseph based on the reciprocal perspective. Sexual violence as one of the great sins that gives the destructive effect to oneself and its environment. Gender relations in existing communities are so discriminatory and patriarchal with the understanding of Quranic verses trying to realize the contemplation of understanding in a safe society of sexual violence.

From the description above, it shows the stigma of female seduction and unmodified interpretation of acts of harassment and violence as illustrated in Zulaikha's story against Joseph. Stigma against one gender is an injustice that is contrary to Islamic justice, therefore it must be stopped. The interpretation that still produces this inequality must be read again. Therefore, the authors assert that this paper seeks to find a friendly understanding with women and men, who are both potential victims of sexual violence.

\section{B. The Causative Factor of Sexual Violence}

Survivors are individuals who struggle from helplessness, including catastrophic and violent conditions. A survivor is a personal individual that we can be categorized as victim when he survives in a state of repeated violence or can we call survivor of violence. Survivors sexual violence expressed an opinion and are going to make the recovery process an outspoken person. Survivors have right, empowered, and the power to defend and not be passive victims. Individuals can be said to the average those who have struggled from the adverse effects of violence they experienced. Through the recovery process, report to the relevant party and exit the condition so destructive. ${ }^{15}$

\footnotetext{
${ }^{14}$ Azman bin Mohd Noor and Ahmad Basri bin Ibrahim, "The Rights of a Rape Victim in Islamic Law," IIUM Law Journal 16, no. 1 (2008): 65-84, https://doi.org/10.31436/iiumlj.v16i1.44.

${ }^{15}$ Ayu Nurfaizah, "Sintas dan Pulih dari Trauma Kekerasan Seksual," Balairung Press, 2019, https://www.balairungpress.com/2019/03/sintas-dan-pulih-dari-trauma-kekerasan-seksual/.
} 
Violence is a form committed by one person to another person with the intention of misery; committing humane actions can be physical or psychological.16 Violence against women includes all actions based on gender differences that impact or are likely to result in physical and sexual misery and suffering for women. These actions include threats of specific actions, coercion, or deprivation of the rights of independence arbitrarily, both that occur in the public sphere and the private sphere. ${ }^{17}$

Violence is a violation of social norms and against religious and social norms. Sexual violence may happen to anyone and at any time. ${ }^{18}$ Data from the National Commission on Violence Against Women shows that sexual violence occurs in all areas, namely personal, public, and state. Sexual violence is the practice of sexual relations carried out in various ways, violence, and contrary to religious teachings. The perpetrator shows violence to prove that he has more power and domination over the victim. ${ }^{19}$

Sexual violence can take various forms, including attempted rape, coercion, sexual harassment, sexual contact with force or threats of force, and the threat of rape. ${ }^{20}$ Sexual violence has a comprehensive scope, ranging from spoken words or dirty comments, indecent behavior such as poking, squeezing, groping, hugging, and so on, displaying bad images, coercion to commit indecent acts such as kissing, threatening women if they refuse to provide sexual services to rape. ${ }^{21}$

National Commission on Violence against Women categorizes sexual violence based on criminal acts in the legislation in force in the Unitary State of the Republic Indonesia. The nine forms of sexual violence are contained in RUU Penghapusan Kekerasan Seksual, including sexual harassment, sexual exploi-

\footnotetext{
${ }^{16}$ Aroma Elmina Martha, Perempuan, Kekerasan dan Hukum (Yogyakarta: UII Press, 2013), 23.

${ }^{17}$ Siti Musdah Mulia, Muslimah Reformis: Perempuan Pembaharu Keagamaan (Bandung: Mizan, 2005), 154.

${ }^{18}$ Kurnia Muhajarah, "Kekerasan terhadap Perempuan dalam Rumah Tangga: Perspektif Sosio-Budaya, Hukum, dan Agama," Sawwa: Jurnal Studi Gender 11, no. 2 (2016): 127-46, https://doi.org/10.21580/sa.v11i2.1452.

${ }^{19}$ Naskah Akademik Rancangan Undang-Undang tentang Penghapusan Kekerasan Seksual, (2019), 77.

${ }^{20}$ Baby Jim Aditya, "Menjadi Sintas: Tindakan dan Upaya Pencegahan dan Pemulihan Kekerasan Seksual," Jurnal Perempuan 21, no. 2 (2016): 47-64.

${ }^{21}$ Elli Nur Hayati, Panduan untuk Pendamping Perempuan Korban Kekerasan (Yogyakarta: Rifka Annisa, 2000), 32-38.
} 
tation, forced use of contraception, coercion for abortion, rape, coercion of marriage, coercion of prostitution, sexual slavery, and self-torture.

The police and the judiciary in Indonesia do not yet have the instrument to resolve the complexity of sexual violence from Indonesian legal systems. This is due to a lack of protection against victims or survivors, triggering sexual assault predators' impunity, the recurrence of cases of sexual violence, and the depression of victims while gaining or absence of recovery and legal justice. ${ }^{22}$

The sexual violence of a particular gender is particular to women, indicating an increasing trend in Indonesia in 2018 is no exception in the domestic or private sphere. We can know that the cause of high levels of violence against women does not arise suddenly; several factors bring up the action, including: first, the emergence of superior and inferior gender classes. Female subordination's position and culture became the forerunner of the emergence of violent behavioral violence against women, including wives. Male domination will always be maintained due to a variety of personal interest to restrict the access of women in developing meeting such as social, economic, political, and so on, this is done because men are in a comfortable position, the hegemony of men who can do anything against women.

Second, the weakness and self-scrutiny. Parents who do not do or have self-stewardship over family members' social environment are the factors that cause their family members to become victims. Both parents are busy with their respective routines. It is parents to equip their children with social ethics even though they are still underage. It should teach embarrassment if their loam is unfolded, teaching were to do urination, including dare to say if any person suspected committing a sexual offense. Besides, self-accuracy does not equip family members with knowledge and useful skills to protect themselves from the threat of sexual crime predators. ${ }^{23}$

Third, permissive attitudes of violence and absolute domination. Violence is often seen as a social phenomenon that is outside of him, not an urgent problem because the victim is a woman who is indeed weak. Such a fact is reinforced by the community's negative labeling that women and children are

\footnotetext{
${ }^{22}$ Komnas Perempuan, "Korban Bersuara, Data Berbicara, Sahkan RUU Penghapusan Kekerasan Seksual sebagai Wujud Komitmen Negara. Catatan Kekerasan terhadap Perempuan Tahun 2018," 2019, https://komnasperempuan.go.id/catatan-tahunan-detail/catahu-2019-korbanbersuara-data-berbicara-sahkan-.

${ }^{23}$ Erich Fromm, Akar Kekerasan: Analisis Sosio-Psikologis atas Watak Manusia (Yogyakarta: Pustaka Pelajar, 2017), 37.
} 
weak individuals, therefore less able to independently, must be governed and led. On the other hand, men become healthy individuals, leading and educating women. Most people ignore the adverse effects of violent acts.

The permissive attitude of violence is to allow any action, including acts of violence committed by men against women, seen as fairness. For example, a husband's beating against his wife or child becomes one of the forms of intimate physical violence and is seen as standard when disputes occur in the household. ${ }^{24}$

Fourth, omission and tendency to close themselves from cases of sexual violence. The majority of victims of violence omit predators of sexual violence without resistance. For them, the sexual violence that happened to them was considered a disgrace for themselves or their families. Victims of violence choose to close themselves to various questions. It makes it challenging to decide violent behavior because predators will assume that they do not harm the victims. ${ }^{25}$

\section{Qirō'ah Mubādalah as a Method for Solving the Sexual Violence Problems}

The method of qirā'ah mubādalah has the meaning of oversight, partnership, and cooperation between men and women in establishing the relationship of life, both in the household and in the wider public life. ${ }^{26}$ Qirä'ah mubādalah is an offer of packaging methods to reinforce the principle of partnership and cooperation between men and women in various verses of the Quran, the text of Hadith, or from similar legal texts. ${ }^{27}$ This method applies to emphasize women and men's position as subjects intended by various sources of text in Islam. ${ }^{28}$

${ }^{24}$ Mufidah Cholil, Psikologi Keluarga Islam Berwawasan Gender (Malang: UIN Maliki Press, 2008), 273.

25Wibisono Wijono, Pedoman Pencegahan Kekerasan Perempuan (Jakarta: Bhakti Husada, 2001), 3.

${ }^{26}$ Faqihuddin Abdul Kodir, "Mafhum Mubadalah: Ikhtiar Memahami Qur'an dan Hadits untuk Meneguhkan Keadilan Resiprokal Islam dalam Isu-Isu Gender," Jurnal Islam Indonesia 6, no. 2 (2016): 1-24; Zakaria Husin Lubis, "Hermeneutics of the Holy Religion Texts (The Study of the Relationships of the Qur'anic Text of Religious Life," Mumtaz: Jurnal Studi Agama dan Keislaman 4, no. 1 (2020): 86-102, https://doi.org/10.36671/mumtaz.v4i01.91.

${ }^{27}$ Neng Dara Affiah, Potret Perempuan Muslim Progresif Indonesia (Jakarta: Yayasan Pustaka Obor Indonesia, 2017), 253.

${ }^{28}$ Faqihuddin Abdul Kodir, Qirā'ah Mubādalah: Tafsir Progresif untuk Keadilan Gender dalam Islam (Yogyakarta: IRCiSoD, 2019), 195. 
Qirä'ah mubādalah transformed into a way to understand the various religious texts and the worldview as a whole. This method responds to primary texts in Islam using certain language conventions and gender awareness and a new way of observing social diversity. ${ }^{29}$ This present is expected to erode relationship inequality and undulation that is sourced from a negative perspective on others. ${ }^{30}$ The methodological step of qirā'ah mubädalah is to the authoritative texts of at least three main steps that need to be passed. ${ }^{31}$ The steps are a sequence to perform the search for the ideal meaning, as follows:

The first step is finding and asserting the various principles of Islamic teaching from the universal text as the basis for the thought, whether general principles transcend all themes or specific to a particular theme.

The second step is finding the main idea manifested in the religious text to be interpreted. In this case, the relational texts have already mentioned women and men's roles. Since the relational text is partial-implementation, it needs to be found the primary meaning and idea that can be cohesive and correlational with the principle asserted by the Quran's verses. This step can be done by eliminating the subject and the object that is in the text, then replacing it with meaning and shuttling that will be analyzed between the two genders. ${ }^{32}$

The third step is shifting the idea and meaning found from the text to the gender not mentioned in the text. Therefore, the text does not stop in one gender only but also includes other genders. ${ }^{33}$

\section{Discussion}

\section{Joseph Prophet as a Symbol Against Victims of Sexual Violence}

By interpreting the Quranic verse, Islam gives the concept of protection to women and daughters. The women were given civil rights as he gave to men

\footnotetext{
${ }^{29}$ Mukhammad Nur Hadi, "Mubadalah Perspective: A Progressive Reading on Book of Dhau' al-Mishbah fi Bayani Ahkam an-Nikah," Islam Universalia 1, no. 3 (2020): 478-515, https://doi.org/ 10.5281/zenodo.3672389.

${ }^{30}$ Kodir, Qirā'ah Mubādalah: Tafsir Progresif untuk Keadilan Gender dalam Islam, 28.

${ }^{31}$ Taufan Anggoro, "The Methodology of Contemporary Gender Interpretation: A Study of Qirā'ah Mubādalah," Sawwa: Jurnal Studi Gender 15, no. 1 (2020): 53-74, https://doi.org/ 10.21580/sa.v15i1.5198.

32Wilis Werdiningsih, "Penerapan Konsep Mubadalah dalam Pola Pengasuhan Anak," IJouGS: Indonesian Journal of Gender Studies 1, no. 1 (2020): 1-16.

${ }^{33}$ Kodir, Qirā'ah Mubādalah: Tafsir Progresifuntuk Keadilan Gender dalam Islam, 198-203.
} 
and eliminated discrimination between women and men to fulfill his civil rights. ${ }^{34}$ Women and men have the same degree in the side of God, except in the case of the primary function following nature. The distinction is not considered to be the opposite, but to complement each other and help. ${ }^{35}$

In Joseph and Zulaikha's story; when the husband discovered that he would do his passion in the form of inviting Joseph to participate and intend to have a body of judges who tried to arbitrate and to find the best solution-assuring the pre-innocent rights to the current behavior. ${ }^{36}$ The judge sought to investigate the chronology of events that befell Joseph and the royal family-trying to find a piece of concrete evidence sitting on the subject of harassment and sexual violence that the person and who is victimized. The chronological evidence and the defense to obtain the Solutive law are shot in QS. Joseph [12] 26-27.37

One of the fundamental rights guaranteed by State institutions is the right to be treated humanely. The man should not make his neighbor a victim of destructive behavior such as violent acts. People live in state institutions whose behavior must be following the value and be reaffirmed without exception legally if he commits acts that violate collective law. Various forms of infringement of women and men's rights, regardless of name and type, should be categorized as a form of deprivation, harassment, and suppression of human dignity. ${ }^{38}$ Speaking of women's violence, the urging is to defend rights and how solutions to restore women who suffer victims of sexual violence. Defending the rights and reconstruction process for women of violence victims is not easy. Recovery of victims, especially sexual violence, needs to consider various aspects such as the victim's physical and psychological aspects. Defending and advocating anti-violence against women is a strategic and measurable step to stem the pace of cases of sexual violence against women in Indonesia.

\footnotetext{
34Yuyun Affandi, Pemberdayaan dan Pendampingan Perempuan Korban Kekerasan Seksual Perspektifal-Qur'an (Semarang: Walisongo Press, 2010).

35Lukman Budi Santoso, "Eksistensi Peran Perempuan sebagai Kepala Keluaraga (Telaah terhadap Counter Legal Draf-Kompilasi Hukum Islam dan Qira'ah Mubadalah," Marwah: Jurnal Perempuan, Agama dan Jender 18, no. 2 (2019), https://doi.org/10.24014/marwah.v18i2.8703.

${ }^{36}$ Ayatullah al-Uzma Nasir Syirazi, Qashas al-Qur'ān (Iran: Mu’assasah Ansariyah, 2005), 125.

${ }^{37}$ Muhammad Akrom, "Analisis Ketampanan Nabi Yusuf dalam Perspektif Semiotika alQur'an," Arabiyat: Jurnal Pendidikan Bahasa Arab dan Kebahasaaraban 1, no. 2 (2014): 223-36, https://doi.org/10.15408/a.v1i2.1141.

${ }^{38}$ Muhammad Fahmi, "Potret Pendidikan Nabi Ya'qub AS kepada Nabi Yusuf AS," Syaikhuna: Jurnal Pendidikan dan Pranata Islam 7, no. 2 (2016): 223-45.
} 
We need to note that violence against women knows no place; it can be in a private or public sphere. Based on National Commission on Violence against Women's annual records, it is precisely in the family or private environment that the highest violence acts occur. Of course, the impact of this is how the related parties formulate regulations that are included in the family environment but still uphold public privacy.

\section{Zulaikha's Domination of Joseph}

Sexual violence against a specific gender, especially against women and children, is a problem that is so complex and generally nuanced gender dominance. Women and children are vulnerable to becoming victims of sexual violence in the domestic sphere. Children are in a weak position and under the control of people who have the authority to determine their lives; for example, father, mother, or older siblings ideally provide protection and love, but the power is misunderstood so that they are vulnerable to violence.

In the case of Joseph's chapter, Zulaikha, who ideally guarantees Joseph's rights, turned instead to be the perpetrator of a violent treatment to fulfill his desire. Violence against women has a contrasting contrast with the perpetrators of violence. When we compare it with violations of human rights in general, the perpetrators are closely related to the role of the pillars of the state.

Different cases of sexual violence against women and children are the perpetrators of the state and the community, even from close family members such as boyfriends, husbands, fathers, neighbors, or people known to the victim. In such a situation, the state's responsibility certainly is not qualified to stem this and requires the community's involvement and various instruments constructed in society such as traditional instruments and instruments of religious understanding about the theme of violence. 39

In addition to the actor aspect, gender understanding is essentially an inherent quality in both culturally and socially constructed men and women. Of course, these characteristics can be exchanged and changed from time to time, different from one place to another, and can differ from one class to another.

The position of women should have equal status and position to men. In women resides with human potential as possessed by men, both from the

\footnotetext{
${ }^{39}$ Komnas Perempuan, Advokasi Kekerasan terhadap Perempuan Oakarta: Komnas Perempuan, 2006), 4.
} 
intellectual, physical or mental, and spiritual aspects. Women are human beings who have all their human potential as men through mind and body. God gives to every human being that cannot be reduced on behalf of anything and by anyone.

Biological differences between women and men have no real influence, necessitating their differentiation in expressing their respective rights and obligations before the law and other social activities. Women have the same rights as men in their various life activities, both in the domestic and public sphere. Quran and Hadith as authoritative sources in Islam, provide an annul text about man's equal position before God, respect for human dignity, and enforcement of justice in behavior and attitude. ${ }^{40}$

\section{The Witness's Assistance to Joseph as a Victims of The Zulaikha's Action}

Accompaniment and assistance to victims of violence, especially sexual violence, include the need for medical, legal, and psychosocial services. Assistance in the context of victim recovery requires a long and steep process to get through it. The inability to provide these three services continuously will make women and children vulnerable.

In addition to law enforcement, aspects of recovery and assistance to victims also need attention. Predators of sexual violence must play a part in taking responsibility for recovery aspects, for example, by paying restitution. It follows some verses of the Quran that mention man tāba wa așlaha, ${ }^{41}$ which implicitly contain the spirit that wants the victim to be returned to his normal condition before he experiences sexual violence. Not only stop there but also Ashlaha, which is repaired. Of course, this is caused (survivors) victims of sexual violence to have long-term physical and psychological effects, which are different from other criminal cases.

The trauma impacts the victims of sexual violence, especially children, in anxiety, fear, emotional, self-closing, and identity crisis. This condition certainly has a significant influence on the perspective, attitude, sexual orientation and then encourages the emergence of immoral behavior as a form of resistance to sexual crime. Sexual crime has torn the trust of children and the authority of parents who have been designed with a solid foundation.

\footnotetext{
${ }^{40}$ Husein Muhammad, Gender dalam Pendekatan Tafsir Maqashidi (Semarang, 2019), 28.

${ }^{41}$ QS. al-Nisā’ [4]: 16.
} 
Victims who experience sexual crimes allow for sexual trauma and tend to reject sexual relations later in life. Feelings of helplessness, self-fear, excessive anxiety, and phobias are often experienced by victims coupled with pain. Feelings of helplessness impact individuals feeling uninspired; victims feel ineffective and able to go through life as it is. ${ }^{42}$

\section{The Strategic Step of The Prophet Joseph to Fight Sexual Violence}

Many factors should have led Joseph to accept the woman's invitation. He is a young man who is not married. The woman's kindness towards Joseph must have been many, and Joseph always followed her orders before that. That woman must have been decorated and wearing fragrances; the palace condition must be comfortable. The doors have been closed tightly. Curtains have been pulled. 43

Flirting is done even with tricks to force many times, which results in torn clothes. It might be that Joseph, as a person who knew the ins and outs of her HouseHouse and personality, knew that even if her husband discovered it, the shrewd wife would be able to avoid it. Moreover, her husband is wildly in love with her. ${ }^{44}$

The Prophet Joseph's strategic step from coercion carried out by Zulaikha can not be separated from a qualified understanding and wisdom or Joseph's wisdom on self-authority and independence from his adoptive confinement mother, Zulaikha. The next main point is that if a human being has and is engraved in science, presents himself with the knowledge that is possessed, and his heart is connected with Allah, it will be easy to get rid of and reject the destructive illegitimate nature of self-existence before God and humans.

In one verse as interpreted by the Quraish Shihab, Allah confirms that indeed I swear, the woman had intended intently to commit iniquity with him because there was no reason, no moral or religion to block it, his desire was overflowing, and he too, that is, Joseph, a handsome and healthy boy, had intended to do it with him if he did not see evidence from his Lord, the wisdom and knowledge bestowed on him.

\footnotetext{
${ }^{42}$ Siti Hikmah, "Mengantisipasi Kejahatan Seksual terhadap Anak melalui Pembelajaran 'Aku Anak Berani Melindungi Diri Sendiri': Studi di Yayasan Al-Hikmah Grobogan," Sawwa: Jurnal Studi Gender 12, no. 2 (2017): 187-206, https://doi.org/10.21580/sa.v12i2.1708.

${ }^{43}$ QS. Yūsuf [12]: 24.

${ }^{44}$ M. Quraish Shihab, Tafsir al-Mishbah: Pesan, Kesan dan Keserasian al-Qur'an, vol. 6 Jakarta: Lentera Hati, 2016), 57.
} 
Evidence from his Lord is what prevents him from doing his will. Thus, that is like that; we turn away from him the perversity of adultery and the abomination which is iniquity. He, Joseph, was among our chosen servants so that Satan could not subdue him. ${ }^{45}$

Joseph's alienation from the great trial was a remarkable event similar to the dream than reality. No one can stem the matter in Joseph so that he can judge such great temptations, except the principle of pure Tauhid, which is faith in Allah or says divine love that fills the whole totality of his form. The divine love has been his heartache, so there is no place in his heart for other than Allah. ${ }^{46}$

The verse means that: For God, the woman has wanted and determined. Furthermore, for God's sake, if Joseph had not seen any evidence of his Lord, he would have been willing and determined and was about to fall into the $\sin$. As the Quraish Shihab quoted the opinion of Tabataba'i, which wrote, "Were it not for the evidence of his lord which he saw, that was the desire and the closeness, even the aboutness or doing it." If so, according to Tabataba'i, the unwillingness, desire, and closeness will not occur.

The circumstance of Joseph is described like that. Even though he has a normal human being when he sees Allah and the evidence that comes from him, never mind his determination or desire, his attention and views are no longer on the woman or another woman. ${ }^{47}$ The verse is concrete proof that the Prophet sent a capacity of faith and Ihsan early on. It is a solid foundation to face experiments that are as great as those at a relatively young age. The situation was so supportive of Joseph to do such behavior, far from his father, unknown to outside parties, and access closed.

Imam Syaukani commented that the word $a l-f a h s h \bar{a}^{\prime}$ or an abomination is everything that exceeds the limit of ugliness. There is an opinion that the word $a l-s \bar{u}^{\prime}$ or its meaning is a betrayal of al-Aziz in his wife, while the word alfahsh $\bar{a}^{\prime}$ is a zinā. There is also the opinion that $a l-s \bar{u}^{\prime}$ is a lousy expression of gratitude. What is more precise is that it is generally common to include everything that the context shows. ${ }^{48}$

\footnotetext{
${ }^{45}$ Shihab, 6:58.

${ }^{46}$ Hamka, Tafsir al-Azhar, 5:3629.

${ }^{47}$ Shihab, Tafsir al-Mishbah 6:59.

48al-Syaukani, Tafsìr Fatḥ al-Qādir al-Jāmi' baina al-Riwāyah wa al-Dirāyah min 'Ilm al-Tafsīr, vol. 5 (Jakarta: Pustaka Azzam, 2011), 575.
} 
Quraish Shihab adds that the word $a l-f a h s h \bar{a}$ ' is a very vile deed. The word is used by the Quran in the context of an unauthorized two-sided relationship and is understood in the sense of adultery. 49 This is in line with the interpretation of the word al-fahsh $\bar{a}^{\prime}$ as the interpretation of al-Qurtuby refers to any speech or bad work, as Ibn' Abbas refers specifically to adultery. ${ }^{50}$

The invitation to commit adultery as separated in QS. Joseph [12]: 24 indicates that the relationship between two opposing types that are not tied in the bonds of marriage is a possible deed to commit adultery. The story of the Prophet Joseph, who was spared from the invitation of Zulaikha to commit adultery, is the picture that people who always do good will get God's help to be safe and far from the behavior of fahsh $\bar{a}^{\prime} \cdot{ }^{\prime}$

The Prophet Joseph in this verse shows including the person who sent his obedience to Allah, on the other side of the Prophet Joseph also included the servant who selected Allah to carry out the treatise. Joseph was a sincere man and was also elected. The reason for him to have them because Joseph was about to escape from the door, while al-Aziz's wife was about to prevent him from being arrested. Because he took them to the door from there, Joseph could save from out of the House. Indeed, Joseph's personal life belongs to mukhlas, an individual who has been consecrated where his pure aspect of the ihrām has been able to with stand the lust and turmoil of him. This is Joseph's outstanding achievement in his life phase. ${ }^{52}$

\section{Implementation of Understanding toward the Prophet Joseph's Story In Resolving Sexual Violence}

The steps taken to apply qirä'ah mubädalah especially verses 23 to 29 in Chapter Joseph, are as follows. The first step refers to a variety of verses that speak of equal faith between women and men, a hymn to do good, and a selfawareness of the slipping of evil deeds. It is the principle of Islamic teachings for women and men. As in QS. al-Nūr [24]: 30 and QS. al-Munāfiqūn [63]: 9, as he

\footnotetext{
${ }^{49}$ Shihab, Tafsir al-Mishbah, 6:60.

${ }^{50}$ Abū Abdullāh Muḥammad ibn Aḥmad ibn Abī Bakar ibn Farah al-Anșāry al-Khazrajy Shamsuddīn Al-Qurțuby, Tafsīr Al-Qurțuby, vol. 13 (Cairo: Dār al-Kutub al-Mișriyah, 1964), 348.

${ }^{51}$ Aḥmad bin Mușțafā al-Marāghy, Tafsīr Al-Marāghy, vol. 12 (Cairo: Maṭba'ah Mușțafā al-Bābi al-Halaby, 1946), 139.

52al-Syaukani, Tafsìr Fath al-Qādir, 5:576.
} 
mentions women and men, the genders remind each other inconsistency doing good and avoiding the prohibition.

The second step, i.e., the main idea of the verse, is to warn people to increase their self-awareness of the world's life charm. This idea comes with involving related verses and eliminating the subject of the object being taken in the verse's predicate. When the subject-object of the verse is omitted, the verse speaks of the self-awareness of the temptation to the charms of another individual.

The third step, i.e., the idea of self-awareness addressed to men of women, in an indirect way of view, also has the meaning that women should also be wary of the charm of men, women, and men to be a source of enchantment from each other. It also has the meaning of both women and men are expected not to spread the charms and increase the self-awareness of possible slip from external parties, regardless of shape. It can be a treasure, a position, a family, a child of sex lust, not confined to the female charm of the male view.

The reading of QS. Joseph [12]: 23 in the framework of the reciprocal or mubādalah commits Tauhid to be the key and basic reasoning and understanding. It implies a point of understanding that in addition to God in an equal position. It is unfair that one feels superior, so it is his neighbor's request. Further, we are in one of the mandatory nature of Allah, that is mukhālafah lil hawädith (unlike the others), then anyone other than him in the same position as well as the mandatory nature of God that is qiyāmuhu binafsihi (stand alone), entrusted us and anything other than himself must need help and interaction with others. Understanding the nature vertically and implementing it in the social horizon will undoubtedly benefit a reciprocal or teamwork.

Tawhid becomes a heart in the body of Islam. All human thought and movement are sourced, directed, and disallowed to uphold the ness of God. The use of tawhìd is essentially the idea of human liberation from various forms of condescension, dignity, discrimination, and human dignity suppression. On the other hand, this theological notion desires to place humanity as a God-made creation that is so respectable with the consequences of human beings appreciating humanity as an independent person, equal in position, and proportionately treating. Self-reliance, tartness, and justice are the original meaning of the implementation of taqwa $\bar{a}$ that we have found in religious texts..$^{53}$

\footnotetext{
${ }^{53}$ Muhammad, Gender dalam Pendekatan Tafsir Maqashidi, 23.
} 
Using tawhìd as the basis of gender issues is no exception in sexual violence. Feminists try to place the principle as a focal point in the cosmos of their thought building and interpretation. The verses on the rights and equality of women are thus widely mentioned in the Quran's verses. The issue has many portions compared to other issues.

Human equality and the absence of gender domination are a manifestation of tawhild. To believe that God almighty over all things trust anything other than him is in equal position without discrimination. Thus, the idea of Hypotheand and the confession and rejection of the Prophet Joseph when harassed by the woman may be sufficient to be the basis for the completion of age issues, including sexual violence in Indonesia.

Believing in the tawhild and only God Almighty only as Joseph believes it, men and women's relationship is between man and woman as slaves. Tauhid does not accommodate a single entity or a God for others. With the middleman of humanitarian relations and this equivalent pregnancy, both men and women must do just one another as defined, ${ }^{54}$ respecting each other based on human dignity ${ }^{55}$ and working together, and helping each other in kindness. ${ }^{56}$

Women as dignified human beings must be fulfilled and acquire their fundamental rights, such as the right of life, religious rights, economic rights, security, and other social rights. Any appropriation and breach of women's rights, including sexual violence by itself, is a waiver of the victim's humanity and the violation of the principles of Godness and the main pillars of the Islamic religion.

\section{E. Conclusion}

Sexual violence occurs in the Prophet Joseph in verbal sexual harassment, torture, and victim-blaming. Sexual violence affects the physical and related to the victim's psychological and emotional problems. The personal strategic step of the Prophet Joseph came out of the circle of sexual violence. It became a survivor or victim who spoke out by implementing monotheism values in various conditions and presenting concrete and chronological evidence of events.

\footnotetext{
${ }^{54}$ QS. al-Nisā' [4]: 135.

${ }^{55}$ QS. al-Isrä' [17]: 70.

${ }^{56}$ QS. al-Tawbah [9]: 71.
} 
The idea of equality between women and men by considering each other's uniqueness becomes a pillar of the Quran's ideals of relationship, mutually exclusive and partnered. Women and men are equally dignified and guaranteed to fulfill their fundamental rights. Violations and struggles for these rights concerning women are a disregard for victims' humanity and a violation of the principle of monotheism in the main pillars of Islam.[s]

\section{References}

Aditya, Baby Jim. "Menjadi Sintas: Tindakan dan Upaya Pencegahan dan Pemulihan Kekerasan Seksual." Jurnal Perempuan 21, no. 2 (2016): 47-64.

Affandi, Yuyun. Pemberdayaan dan Pendampingan Perempuan Korban Kekerasan Seksual Perspektifal-Qur'an. Semarang: Walisongo Press, 2010.

Affiah, Neng Dara. Potret Perempuan Muslim Progresif Indonesia. Jakarta: Yayasan Pustaka Obor Indonesia, 2017.

Akrom, Muhammad. "Analisis Ketampanan Nabi Yusuf dalam Perspektif Semiotika alQur'an." Arabiyat: Jurnal Pendidikan Bahasa Arab dan Kebahasaaraban 1, no. 2 (2014): 223-36. https://doi.org/10.15408/a.v1i2.1141.

Anggoro, Taufan. "The Methodology of Contemporary Gender Interpretation: A Study of Qirāah Mubādalah." Sawwa: Jurnal Studi Gender 15, no. 1 (2020): 53-74. https://doi.org/10.21580/sa.v15i1.5198.

Arani, Amirudin, and Faqihuddin Abdul Kodir. Tubuh, Seksualitas dan Kedaulatan Perempuan. Yogyakarta: Rahima, 2002.

Cholil, Mufidah. Psikologi Keluarga Islam Berwawasan Gender. Malang: UIN Maliki Press, 2008.

Ciciek, Farha. Ikthiar Mengatasi Kekerasan dalam Rumah Tangga. Jakarta: The Asian Foundation, 1999.

Fahmi, Muhammad. "Potret Pendidikan Nabi Ya'qub AS kepada Nabi Yusuf AS." Syaikhuna: Jurnal Pendidikan dan Pranata Islam 7, no. 2 (2016): 223-45.

Fromm, Erich. Akar Kekerasan: Analisis Sosio-Psikologis atas Watak Manusia. Yogyakarta: Pustaka Pelajar, 2017.

Hadi, Mukhammad Nur. "Mubadalah Perspective: A Progressive Reading on Book of Dhau' al-Mishbah fi Bayani Ahkam an-Nikah." Islam Universalia 1, no. 3 (2020): 478-515. https://doi.org/10.5281/zenodo.3672389. 
Hamka. Tafsir al-Azhar. Vol. 5. Singapura: Pustaka Nasional PTE Ltd., 1990.

Hayati, Elli Nur. Panduan untuk Pendamping Perempuan Korban Kekerasan. Yogyakarta: Rifka Annisa, 2000.

Hikmah, Siti. "Mengantisipasi Kejahatan Seksual terhadap Anak melalui Pembelajaran 'Aku Anak Berani Melindungi Diri Sendiri': Studi di Yayasan al-Hikmah Grobogan." Sawwa: Jurnal Studi Gender 12, no. 2 (September 10, 2017): 187-206. https://doi.org/10.21580/sa.v12i2.1708.

Ismail, Nurjannah. Perempuan dalam Pasungan Bias Laki-Laki dalam Penafsiran. Yogyakarta: LKiS, 2003.

Kodir, Faqihuddin Abdul. "Mafhum Mubadalah: Ikhtiar Memahami Qur'an dan Hadits Untuk Meneguhkan Keadilan Resiprokal Islam dalam Isu-Isu Gender." Jurnal Islam Indonesia 6, no. 2 (2016): 1-24.

___. Qirā'ah Mubādalah: Tafsir Progresif Untuk Keadilan Gender dalam Islam. Yogyakarta: IRCiSoD, 2019.

Komisi Nasional Anti Kekerasan terhadap Perempuan. "Lembar Fakta dan Catatan Tahunan Komnas Perempuan Tahun 2018.” Jakarta: Komnas Perempuan, 2018.

Komnas Perempuan. Advokasi Kekerasan terhadap Perempuan. Jakarta: Komnas Perempuan, 2006.

__ _. "Korban Bersuara, Data Berbicara, Sahkan RUU Penghapusan Kekerasan Seksual sebagai Wujud Komitmen Negara. Catatan Kekerasan terhadap Perempuan Tahun 2018," 2019. https://komnasperempuan.go.id/catatantahunan-detail/catahu-2019-korban-bersuara-data-berbicara-sahkan-.

Lubis, Zakaria Husin. "Hermeneutics of the Holy Religion Texts (The Study of the Relationships of the Qur'anic Text of Religious Life." Mumtaz: Jurnal Studi Agama dan Keislaman 4, no. 1 (2020): 86-102. https://doi.org/10.36671/mumtaz. v4i01.91.

al-Marāghy, Aḥmad bin Muṣțafā. Tafsīr al-Marāghy. Vol. 12. Cairo: Maṭba'ah Mușțafã alBābi al-Halaby, 1946.

Martha, Aroma Elmina. Perempuan, Kekerasan dan Hukum. Yogyakarta: UII Press, 2013.

Maudy, Citra. "Nalar Pincang UGM atas Kasus Perkosaan." Balairung Press, 2018. https://www.balairungpress.com/2018/11/nalar-pincang-ugm-atas-kasusperkosaan/.

Muhajarah, Kurnia. "Kekerasan terhadap Perempuan dalam Rumah Tangga: Perspektif Sosio-Budaya, Hukum, dan Agama." Sawwa: Jurnal Studi Gender 11, no. 2 (2016): 127-46. https://doi.org/10.21580/sa.v11i2.1452.

Muhammad, Husein. Gender dalam Pendekatan Tafsir Maqashidi. Semarang, 2019. 
Mulia, Siti Musdah. Muslimah Reformis: Perempuan Pembaharu Keagamaan. Bandung: Mizan, 2005.

Nathaniel, Felix. "Baiq Nuril, Korban Pelecehan Seksual yang Dipidana Gara-Gara UU ITE." Tirto.ID, 2018. https://tirto.id/baiq-nuril-korban-pelecehan-seksual-yangdipidana-gara-gara-uu-ite-c9QH.

Nick, Raistick. Reporting on Gender Based Violence in the Syiria Crisis: A Journalist's Handbook. England: UNFPA, 2014.

Noor, Azman bin Mohd, and Ahmad Basri bin Ibrahim. "The Rights of a Rape Victim in Islamic Law." IIUM Law Journal 16, no. 1 (2008): 65-84. https://doi.org/ 10.31436/iiumlj.v16i1.44.

Noor, Mariam Nabilah Mohd, and Mohd Shafiee Hamzah. "Defamation by Women Mentioned in Surah Yusuf According to Hamka: A Review." International Journal of Academic Research in Business and Social Sciences 7, no. 12 (2018): 631-39. https://doi.org/10.6007/IJARBSS/v7-i12/3645.

Nurfaizah, Ayu. "Sintas dan Pulih dari Trauma Kekerasan Seksual." Balairung Press, 2019. https://www.balairungpress.com/2019/03/sintas-dan-pulih-dari-traumakekerasan-seksual/.

al-Qurțuby, Abū Abdullāh Muhammad ibn Aḥmad ibn Abī Bakar ibn Farah al-Anșāry alKhazrajy Shamsuddīn. Tafsìr al-Qurțbyy. Vol. 13. Cairo: Dār al-Kutub al-Mișriyah, 1964.

Sa'dan, Masthuriyah. "Reinterpretasi Teologi Kekerasan Seksual terhadap Perempuan: Kajian Tafsir Amina Wadud." Jurnal Perempuan 21, no. 2 (2016): 163-70.

Santoso, Lukman Budi. "Eksistensi Peran Perempuan sebagai Kepala Keluaraga (Telaah terhadap Counter Legal Draf-Kompilasi Hukum Islm dan Qira'ah Mubadalah." Marwah: Jurnal Perempuan, Agama dan Jender 18, no. 2 (2019): 107-120.https://doi.org/10.24014/marwah.v18i2.8703.

Shihab, M.Quraish. Tafsir Al-Mishbah: Pesan, Kesan dan Keserasian al-Qur'an. Vol. 6. Jakarta: Lentera Hati, 2016.

al-Syaukani. Tafsìr Fath al-Qādir al-Jāmi' baina al-Riwāyah wa al-Dirāyah min 'Ilm alTafsir. Vol. 5. Jakarta: Pustaka Azzam, 2011.

Syirazi, Ayatullah al-Uzma Nasir. Qashas al-Qur'ān. Iran: Mu'assasah Ansariyah, 2005.

Werdiningsih, Wilis. "Penerapan Konsep Mubadalah Dalam Pola Pengasuhan Anak." IJouGS: Indonesian Journal of Gender Studies 1, no. 1 (2020): 1-16.

Wijono, Wibisono. Pedoman Pencegahan Kekerasan Perempuan. Jakarta: Bhakti Husada, 2001. 